\title{
Wybory, których nie było
}

Images

vol. X/no. 19

Poznań 2012

ISSN 1731-45OX
Licznie zamieszkujący świat „człowiek w rozterce” to obiekt szczególnego zainteresowania sztuk wszelkiej maści. Jest więc skarbnicą także i filmowego potencjału. Właściwie wszystkie gatunki filmowe są $\mathrm{w}$ stanie zrobić użytek $\mathrm{z}$ dylematu bohatera: melodramaty - czyniąc z niego trzon relacji międzyludzkich, filmy sensacyjne - wspomagając nim poziom budowanego napięcia, psychologiczne - definiując za jego pomocą charakter postaci i trudności jej życia, komedie - trudności te karykaturalnie przerysowując. Wszechobecne wybory i decyzje inspirują też twórców krótkich form studenckich. Spośród niezliczonych ich przykładów wyłaniają się trzy zrealizowane w 2010 roku i dotykające problemów najaktualniejszych. Tym, co łączy poniższe etiudy, tak przecież odmienne stylistycznie, jest znajdujący się w trudnym położeniu bohater. Jednak okoliczności, w których znalazła się każda $\mathrm{z}$ występujących w poniżej omówionych filmach postaci, są o tyle specyficzne, że to nie sam fakt stanięcia przed niewyobrażalnie trudnym wyborem świadczy o beznadziejności ich sytuacji. To raczej niemożliwość suwerennego i w pełni świadomego zmierzenia się z owym wyborem - w obliczu przeszkód natury psychicznej i społecznej.

Sytuacja fabularna w filmie animowanym Krzysztofa Szafrańca Wino jest ledwie zarysowana. I to zarówno dosłownie - z uwagi na zastosowaną przez autora technikę widzimy naszkicowane czarną kreską kontury postaci poruszających się po białym tle, jak i w przenośni - gdyż zaburzona chronologia zdarzeń uniemożliwia precyzyjne odtworzenie przedstawionej sytuacji, zacierając granicę między przyczyną a skutkiem, między prawdą a urojeniem.

Filmowe wydarzenia osadzone są w kontekście alkoholizmu na miarę XXI stulecia - skrapianego eleganckim winem, podszytego samotnością, towarzyszącego stanom depresyjnym. Wiadomo jest, że niemy, bezimienny bohater stracił przyjaciela, nad którego trumną stoi w jednej z pierwszych scen, oraz że otrzymał niegdyś od niego kieliszki do czerwonego wina. I na tym właściwie kończy się to, co pewne. Wydaje się bowiem, że posługiwanie się niemal samymi animacyjnymi półproduktami jest czymś więcej niż estetycznym wyborem reżysera. Wizualna asceza przede wszystkim subiektywizuje punkt widzenia, obrazując zniewolenie podmiotu. Elementy scenerii pojawiają się na potrzeby danej czynności i chwilę później zupełnie znikają, co jest odwzorowaniem ograniczonej percepcji bohatera. Przez tę prostą ekonomiczność znaczeń, czy może raczej ich wybiórczość, manipuluje się również uwagą odbiorcy. Pozbawiony dostępu do pełni infor-
W winie prawda 
macji, nie tylko nie może dokonać właściwej oceny zachowania miotającego się bohatera, ale nawet ustalić, co naprawdę zdarzyło się w jego życiu oraz kim właściwie jest pojawiający się w dalszych scenach przyjaciel.

Demoniczny podżegacz, w którego stopniowo przeobraża się ów kompan, może być zarówno prawdziwą osobą, winną choroby alkoholowej głównego bohatera, jak i zdeformowaną projekcją jego wspomnień albo uosobieniem tchórzliwego samousprawiedliwiania. Trudno też orzec, czy w kluczowej scenie samobójstwa udaremniający je życzliwy przyjaciel jest częścią autentycznego wspomnienia czy raczej omamem (wszak dominująca narrację „teraźniejszość” dzieje się już po jego śmierci). Pierwszy przypadek stanowiłby wyjaśnienie genezy silnej przyjaźni między postaciami. Wówczas alkoholizm, w który wpadnie później główny bohater, byłby efektem rozpaczy i próbą zagłuszenia żalu po stracie bliskiej osoby. Jeśli jednak scena na pomoście nie wychodzi poza chronologię, to przyjaciel jest majakiem, a bohater alkoholikiem, wówczas to nałóg paradoksalnie ratuje przed śmiercią - jako alternatywa atrakcyjniejsza, umożliwiająca bezkarne życie w złudnym świecie wspomnień.

Wreszcie - wybór, przed którym staje niezdolny do niego bohater, dotyczy życia i śmierci. Życia - pełnego, prawdziwego, bez nałogu. Śmierci - takiej samej, do której zbliżył się już poprzednio. W tym celu w finale filmu, na jawie lub we śnie, pijany bohater wraca na pomost. Lecz nałóg nie pozwala mu podjąć żadnej decyzji i bohater ostatecznie osiada na swoim prywatnym rozdrożu $-\mathrm{z}$ butelką $\mathrm{w}$ dłoni i „przyjacielem” u boku.

Nocny pociąg donikąd
Fabularnych niedomówień unika z kolei Bartłomiej Żmuda w swoim filmie Barbakan, który uderza autentyzmem spojrzenia i precyzją budowy portretu psychologicznego głównego bohatera. Po pewnym czasie spędzonym przy pracy na niemieckiej budowie Emil z radością wraca do Krakowa i czekającej na niego Ani. Tuż przed przyjazdem do Warszawy, gdzie przesiąść się ma w tytułowy ekspres Barbakan, chłopak zostaje okradziony ze wszystkich ciężko zarobionych pieniędzy. Z kilkoma złotymi w portfelu decyduje się jednak odbyć kluczową podróż swojego życia.

Wszystko to, co widzimy na ekranie, jest jedynie następstwem procesów myślowych Emila. Istota filmowych wydarzeń rozgrywa się bowiem w umyśle bohatera, do którego kamera nie ma dostępu, a który zbadać można analizując jego zachowania. Opierają się one na konstrukcji złożonej z trzech rozpoznań. Pierwsze $\mathrm{z}$ nich, najbardziej oczywiste, dokonuje się przy dworcowej kasie, gdy Emil orientuje się, że nie ma pieniędzy. Wówczas daje upust swoim emocjom - krzyczy, rzuca torbą, ma łzy w oczach. Później przez dłuższy czas będzie je tłumił, co doprowadzi go do granicy obłędu.

Kluczowe jest jednak to, że Emil nikogo nie obarcza winą za zaistniałą sytuację. Wypiera ją raczej ze swojej świadomości, co czyni 
go niezdolnym do podjęcia próby odpowiedzenia sobie na pytanie „co dalej?”. O owej negacji świadczy seria zachowań chłopaka: ukrywa swój problem przed wszystkimi - również przed swoją dziewczyną, nie zgłasza kradzieży policji, nie czeka na inny, tańszy pociąg do Krakowa i nie zmieniając planów, wsiada do tego, na który nie ma biletu. Nie unika nawet kontroli, a przyłapany, honorowo nie chce przyjąć pożyczki od współpasażera, Karola, który protekcjonalnie go do tego zmusza.

Na pół godziny przed końcem podróży następuje drugie rozpoznanie. Emil wpada na pomysł wyjścia z impasu przez kradzież laptopa i grubego portfela Karola. Dylemat, który powinien rozstrzygnąć, w ogóle się nie pojawia, gdyż Emil, paraliżując swoje sumienie, odrzuca konieczność zastanowienia się. Działa w amoku i pragnie zagłuszyć własną stratę prymitywną potrzebą poczucia równowagi w przyrodzie. Emil nie zdaje sobie jednak sprawy, że odpowiedzenie kradzieżą na kradzież przyniosłoby mu spokój tylko wtedy, gdyby okradł osobę, która okradła jego. A to jest przecież niewykonalne. Chłopak przestaje zachowywać się racjonalnie - ignoruje fakt przebywania w szczelnej pułapce wyizolowanej przestrzeni, zapomina też, że jako „ten bez biletu” musiał dać się zapamiętać konduktorowi i współpasażerom.

W efekcie wyskakuje z pociągu. Mimo iż jego fizyczne obrażenia kończą się na kilku zadrapaniach, psychicznie jest wyprany doszczętnie. W jego oczach nie ma już nawet wcześniejszego obłędu jest pustka. Nagle wypełnia ją odbicie pociągu przejeżdżającego o włos od Emila. Na szczęście przejechał innym torem, lecz kto wie, czy tym razem chłopak nie zdecyduje się jednak zaczekać na kolejny pociąg. Wówczas dokonać się może trzecie rozpoznanie - tym razem zbieżne $\mathrm{z}$ antycznym anagnorisis i prowadzące do finalnej autodestrukcji. Lecz z tym wyborem Emil zmierzy się już poza ekranem.

O tym, jak bardzo Szwedzka robota różni się od robót włoskich i angielskich - dobrze znanych kinu, przekonujemy się w niemal każdej minucie filmu. Paweł Ziemilski w poetyce groteski i absurdu przerysowuje nie tylko okoliczności autentycznych wydarzeń - związanych z kradzieżą napisu z bramy byłego hitlerowskiego obozu koncentracyjnego w Oświęcimiu, ale przede wszystkim radośnie spekuluje na temat bohaterów, wykonawców zlecenia. Najzuchwalsi polscy złoczyńcy roku 2009 są w filmie nieudolnymi rzezimieszkami i daleko im do profesjonalizmu w złodziejskim kunszcie.

Szef przedsięwzięcia, Romek („ja mówię, wy robicie”), nie panuje nad jego przebiegiem, a podlegli mu bracia Mysze zdają się nie rozumieć jego celu. Wbrew późniejszym doniesieniom mediów o dobrze zaplanowanej i przeprowadzonej akcji ich działania są swobodną improwizacją. Z początku zlecenie jest dla nich wszystkich przygodą, co podkreśla sekwencja jazdy samochodem - stylem przypominająca miłe kino drogi. Po przyjeździe na miejsce mającej się dokonać kradzieży, dla Romka i Małego Myszy przygoda zamienia się w zadanie do wykonania. Natomiast Duży Mysza orientuje się, dokąd

Przypadkowi
wrogowie publiczni 
przybył. „Ale przecież to jest Oświęcim” - jedne z nielicznych słów, które wypowiada w filmie, wyrażają niepokój, moralny sprzeciw, świadomość niestosowności czynu. I choć nie wydaje się uspokojony przekonywaniami brata, że „to tylko napis” i że „teraz nie ma już odwrotu”, przystępuje do wykonania zlecenia.

Ta krytyczna chwila zwątpienia powinna zaowocować inną decyzją. Czy jednak można w ogóle mówić o tym, że Duży Mysza dokonał jakiegokolwiek wyboru? Jedno jest pewne: nigdy nie przestał przeczuwać, że bierze udział w czymś niewłaściwym. W nocy po rabunku nie może spać, a jego niewzruszona twarz przez dłuższą część filmu nie wyraża emocji innych niż te związane ze sprawą napisu - jak niepokój przy jego zdejmowaniu i wstyd podczas słuchania w telewizji głosów potępienia dla sprawców kradzieży.

Duży Mysza to, jak się okazuje, osoba wrażliwa, społecznie otwarta oraz świadoma przeszłości swojego kraju. Niewiarygodnie szybko asymiluje się z wycieczką młodych turystów z Izraela, wśród których wygląda na naprawdę szczęśliwego. Zapytany przez Romka, na co wyda zarobione w akcji sześć tysięcy złotych, odpowiada, że zbuduje dom. I choć te naiwne słowa doprowadzą jego towarzyszy do ataku śmiechu, zabrzmią stokroć dojrzalej od całkiem realistycznych planów Małego Myszy, który planuje dzięki swoim pieniądzom przez rok odurzać się kokainą.

Problemem Dużego Myszy, uniemożliwiającym mu wzięcie życia w swoje ręce, musi być bardzo niskie poczucie własnej wartości. Jego instynktowna poczciwość jest nie tylko niepopularna w środowisku, w którym przebywa, ale i przez nie uciszana. Tę niezdolność do podjęcia samodzielnej decyzji rekompensują mu scenarzyści. Bo nie dość, że Duży Mysza jest jedyną postacią potraktowaną poważnie i psychologicznie pogłębioną, to jeszcze odnajduje ludzi, wśród których czuje się spełniony $\mathrm{i}$ - wbrew finałowi historii w prawdziwym świecie - nie zostaje zatrzymany przez policję.

Młodzi filmowcy kierują uwagę na sytuacje, w których życiowym problemem nie jest konieczność dokonania trudnego wyboru. Większą tragedią okazuje się niemożliwość zbliżenia się do niego, doświadczenie pozbawienia szansy na stawienie mu czoła. Realia dzisiejszego świata doprowadzają do frustrujących okoliczności, kiedy wolności pozbawia nałóg - jak w przypadku bohatera Wina, rozpacz - u Emila z Barbakanu, a także życie w przekonaniu o własnej niższości - czego doświadcza Duży Mysza. Każdy z nich znalazł się w przełomowym momencie swojego życia, które w ostatnim czasie nie dało im sposobności postanawiania o sobie. Jeśli zdadzą sobie $\mathrm{z}$ tego sprawę i wyciągną odpowiednie wnioski, będą mogli zawalczyć o należne im prawo głosu.

Dylemat zatem to nie tylko efekt uboczny rosnącej swobody wyboru człowieka - to też jego święte prawo. Najboleśniejsze bowiem są decyzje trudne. Najszkodliwsze - niepodjęte. 